\title{
Oea
}

JURNAL PENDIDIKAN GEOGRAFI

\section{PENERAPAN TEKNIK PETA PIKIRAN (MIND MAP) UNTUK MENINGKATKAN PEMAHAMAN KONSEP GEOGRAFI PADA PESERTA DIDIK KELAS XI-2 IPS SMAN 1 RASAU JAYA KABUPATEN KUBU RAYA}

\author{
Diah Trismi Harjanti ${ }^{1}$, Epon Ningrum ${ }^{2}$, Ahmad Yani $^{3}$ \\ ${ }^{1}$ Mahasiswa Prodi Geografi, SPs, UPI, email: geoplanolog@gmail.com \\ 2Jurusan Pendidikan Geografi, FPIPS, UPI, email: epon.ningrum@yahoo.com \\ ${ }^{3}$ Jurusan Pendidikan Geografi, FPIPS, UPI, email: ahyani_07@yahoo.co.id
}

\begin{abstract}
ABSTRAK
Penelitian ini dilatarbelakangai oleh lemahnya pemahaman konsep geografi peserta didik di SMAN 1 Rasau Jaya. penyebab lemahnya pemahaman konsep geografi adalah materi ajar yang sangat banyak pada setiap pokok bahasannya membuat guru sering memilih memberikan tugas meringkas materi dan mendiktekan materi kepada peserta didik disetiap pertemuannya. Salah satu upaya untuk mengetahui peningkatan pemahaman konsep geografi peserta didik adalah dengan dapat menerapkan teknik peta pikiran. Penelitian ini juga dapat mengetahui hambatan yang dihadapi selama penerapan teknik peta pikiran. Penelitian ini menggunakan desain Penelitian Tindakan kelas (PTK) yang dilaksanakan di SMAN 1 Rasau Jaya pada semester genap. Subjek penelitian adalah peserta didik kelas XI IPS 2 dengan jumlah peserta didik 24, peserta didik laki-laki 12 dan peserta didik perempuan 12. Rencana tindakan dilaksanakan melalui dua siklus dan disetiap siklusnya terdiri dari dua tindakan. Adapun dalam setiap tindakan terdiri dari tiga kegiatan yaitu: perencanaan (planning), pelaksanaan (action), dan refleksi (reflection). Indikator keberhasilan yang ditetapkan apabila 75\% dari jumlah peserta didik atau sekitar 18 peserta didik mencapai KKM. Hasil penelitian menunjukkan adanya peningkatan pemahaman konsep geografi peserta didik melalui penerapan teknik peta pikiran (Mind Map) pada mata pelajaran geografi. Peningkatan tersebut dapat dilihat dari setiap tindakan yang dilakukan. Hambatan yang dihadapi selama pelaksanaan penelitian diantaranya keterbatasan waktu penelitian, penguasaan langkah-langkah teknik pembelajaran, manajemen waktu yang kurang baik oleh guru model, dan kurangnya minat peserta didik dalam membaca dan menulis. Kesimpulannya, teknik peta pikiran (Mind Map) dapat meningkatkan pemahaman konsep geografi peserta didik. Rekomendasi dalam penelitian ini adalah guru dapat mencoba menggunakan teknik peta pikiran untuk pembelajaran selanjutnya, selain dapat mempermudah dalam penyampaian pokok bahasan yang banyak juga dapat melatih guru dalam penggunaan waktu yang efisien., melatih minat baca dan menulis peserta didik serta melatih ketekunan, ketelitian dan kesabaran peserta didik.
\end{abstract}

Kata kunci: teknik peta pikiran, pemahaman konsep, penelitian tindakan kelas. 


\section{Pendahuluan}

Pada tingkatan belajar terdapat dua tingkatan yaitu; belajar penerimaan atau belajar penemuan dan belajar bermakna. Bentuk belajar penerimaan yaitu menyajikan informasi dalam bentuk final yang mengharuskan peserta didik menemukan sendiri sebagian atau seluruh materi yang diajarkan sedangkan belajar bermakna peserta didik menghubungkan atau mengkaitkan informasi pada pengetahuan (berupa konsep atau lainnya) yang telah dimiliki. Menurut Ausubel (1963 dalam Dahar 98: 2006), faktor utama yang mempengaruhi belajar bermakna adalah struktur kognitif yang ada, stabilitas dan kejelasan pengetahuan dalam suatu bidang studi tertentu dan pada waktu tertentu.

Pembelajaran yang memiliki tujuan untuk meningkatkan pemahaman konsep peserta didik maka tingkatan pembelajaran yang digunakan adalah belajar bermakna. Sebab, dalam belajar bermakna peserta didik belajar cara menyimpan pengetahuan ke dalam otak sehingga sel-sel otak akan menyimpan informasi yang mirip dengan informasi yang sedang dipelajari. Untuk mendapatkan pemahaman konsep seorang peserta didik harus mampu mengidentifikasi, mengkalisifikasikan atau mengelompokkan, serta mengeneralisasikan suatu peristiwa, objek, dan kegiatan yang dijumpainya dalam kehidupan sehari-hari.

Materi ajar pada geografi yang banyak disetiap pokok bahasan, namun alokasi waktu yang ada sedikit menyebabkan guru lebih memilih memberikan tugas kepada peserta didik dalam bentuk meringkas materi dengan tujuan peserta didik akan lebih mudah memahami konsep yang ada pada materi yang sedang diajarkan tanpa menjelaskan lebih rinci materi tersebut. Namun yang terjadi peserta didik merasa belum paham dengan materi pokok yang ada sudah harus memulai lagi dengan materi yang baru. Hal ini menyebabkan timbulnya rasa jenuh, tidak bersemangat dalam proses belajar mengajar, serta peserta didik tidak tertarik dengan materi yang disampaikan oleh guru. Selain itu guru juga sering mendiktekan materi ajar kepada peserta didik dan tugas yang diberikan adalah menghafal.

Hal yang paling dibutuhkan dalam proses belajar mengajar adalah kreativitas seorang guru dalam mengajar sehingga pembelajaran menjadi menarik. Kegiatan belajar yang dilaksanakan haruslah berpusat pada peserta didik, guru hanya sebagai motivator dan fasilitator, dan guru harus bisa mendorong peerta didik agar dapat belajar mengkonstruksi sendiri pengetahuannya melalui berbagai aktivitas belajar. Sehingga saat peserta didik diberi kesempatan untuk mengkonstruksi pengetahuannya sendiri peserta didik dengan mudah akan memahami konsep-konsep yang diajarkan.

Untuk itu diperlukan sebuah teknik pembelajaran yang bisa mendorong peserta didik dalam mengkonstruksi materi diterima di sekolah dan disesuaikan dengan pengalaman peserta didik, sehingga dengan mudah dapat memahami konsep-konsep yang diajarkan. Teknik peta pikiran merupakan teknik pembelajaran yang tidak mengharuskan peserta didik menghafal fakta-fakta, tetapi sebuah teknik pembelajaran yang mendorong peserta didik mengkontruksikan suatu konsep dibenak mereka sendiri.

Tujuan penelitian ini adalah: (1) Meningkatkan pemahaman konsep geografi melalui teknik peta pikiran pada peserta didik kelas XI-2 IPS SMAN 1 Rasau Jaya, (2) Menggunakan teknik peta pikiran untuk meningkatkan pemahaman konsep geografi pada peserta didik kelas XI-2 IPS SMAN 1 Rasau Jaya. (3) Mengidentifikasi hambatan yang dihadapi dalam penggunaan teknik Peta Pikiran selama pelaksanaan penelitian tindakan kelas pada peserta didik kelas XI-2 IPS SMAN 1 Rasau Jaya.

Hasil dari peneilitain ini diharapkan dapat memberikan memberikan gambaran secara menyeluruh tentang teori peta pikiran serta teori pemahaman konsep sehingga pembelajaran geografi dapat mengembangkan pengetahuan dan penalaran sehingga kegiatan pembelajaran dapat dilakukan secara interaktif, inspiratif, menyenangkan, menantang, serta memotivasi peserta didik untuk berpartisipasi aktif, serta memberikan ruang yang cukup bagi prakarsa, kreativitas, dan kemandirian sesuai dengan bakat, minat, perkembangan fisik serta psikologis peserta didik. Selain itu dapat memberikan sumbangan pegetahuan bagi guru, sekolah maupun Lembaga Pendidikan Tenaga Kependidikan (LPTK). 


\section{Penjelasan Istilah}

a. Teknik peta pikiran

Menurut Sumarmi (2012: 75) peta pikiran merupakan suatu cara untuk mengemukakan hal yang dipikirkan melalui suatu catatan yang menggambarkan hubungan antarkata, warna, dan gambar sehingga materi dapat dipahami dan diingat. Prinsipnya teknik peta pikiran dapat mempermudah peserta didik memahami suatu pokok bahasan sesuai dengan pikiran setiap peserta didik.

\section{b. Pemahaman Konsep}

Bloom (1956: 89) dalam Muhibinsyah Muhibbinsyah (2013:25), menyatakan bahwa "pemahaaman mencakup tujuan, tingkah laku, atau tanggapan yang mencerminkan sesuatu pemahaman pesan tertulis yang termuat dalam satu komunikasi”. Sehingga peserta didik dituntut memahami atau mengerti apa yang diajarkan, mengetahui apa yang sedang dikomunikasikan dan dapat memanfaatkan isinya tanpa keharusan menghubungkan dengan hal-hal yang lain. Peserta didik dikatakan paham terhadap sesuatu materi ajar, apabila peserta didik dapat mengerti benar dan mampu menjelaskan kembali materi ajar tersebut.

Bloom menyatakan (1978: 90) "Pemahaman konsep yang diukur terdiri dari tiga kategori, yaitu menterjemahkan, menafsirkan, dan mengekstrapolasi”. Dari ketiga indikator pemahaman konsep tersebut aspek-aspek yang menjadi pengukuran pemahaman konsep peserta didik yaitu: pembuatan peta pikiran, hasil presentasi peta pikiran, lembar kerja peserta didik dan tes akhir.

\section{Metode penelitian}

\section{a. Tempat dan waktu penelitian}

Lokasi penelitian ini akan dilaksanakan di SMAN 1 Rasau Jaya pada Mata Pelajaran Geografi di Kelas XI-2 IPS tahun ajaran 2013/2014. SMAN 1 Rasau Jaya berada di Jalan Pendidikan No.6 Desa Rasau Jaya I Kecamatan Rasau Jaya Kabupaten Kubu Raya Provinsi Kalimantan Barat. Peserta didik yang dijadikan subjek penelitian adalah peserta didik kelas XI-2 IPS dengan jumlah peserta didik 24, yang terdiri dari 12 peserta didik laki-laki dan 12 peserta didik perempuan. Peneliti bertindak sebagai observer dan guru bidang studi geografi kelas XI SMAN 1 Rasau Jaya bertindak sebagai pelaksana tindakan. Penelitian ini akan dilaksanakan pada semester ganjil pada tahun ajaran 2013/2014, yaitu pada bulan Juli sampai Desember 2013.

\section{b. Desain Penelitian}

Pada penelitian ini desain penelitan yang gunakan adalah Penelitian Tindakan Kelas (PTK). Penelitian ini dilakukan dalam empat kegiatan pokok yaitu, Perencanaan, Tindakan, Observasi dan Refleksi serta dalam satu siklus terdiri dari dua tindakan. Adapun faktor yang dikaji meliputi; (1) peningkatan pemahaman konsep geografi peserta didik dengan cara membuat peta pikiran. Peningkatan tersebut diukur melalui kemampuan peserta didik dalam pembuatan peta pikiran, presentasi peta pikiran, mengerjakan tes tertulis dan LKS, serta (2) penggunaan teknik peta pikiran pada sub materi pokok biosfer bertujuan untuk meningkatkan pemahaman konsep geografi peserta didik kelas XI-IPS2 serta bisa dijadikan pertimbangan alternatif pengajaran.

\section{c. Instrument Penelitian}

Untuk memperoleh data penelitian maka peneliti menggunakan lembar observasi untuk mengamati aktivitas guru dalam pelaksanaan pembelajaran, test untuk mengukur pemahaman peserta didik, lembar kerja peserta didik untuk mengukur aktivitas peserta didik selama pelaksanaan tindakan lembar peta pikiran untuk mengukur keberhasilan teknik peta pikiran dalam meningkatkan pemahaman konsep dan presentasi untuk mengukur kemampuan dan keaktifan peserta didik dalam mempresentasikan hasil peta pikirannya. 


\section{d. Teknik Analisis Data}

Data yang dikumpulkan dari penelitian ini terdiri dari; (1) Data kuantitatif dianalisis secara statistik sederhana yaitu prosentase sehingga diperoleh hasil yang nantinya akan dibandingkan dengan KKM dan nilai peserta didik sebelum penelitian tindakan kelas ini dapat dikatakan berhasil atau tidak; (2) Peta pikiran yang telah dikerjakan oleh peserta didik di nilai menggunakan kriteria penilaian, yaitu: (a) kesahihan proporsisi, (b) adanya hierarki, (c) adanya ikatan silang, dan (d) adanya contoh-contoh; dan (3) Data kualitatif dianalisis secara kualitatif yang diperuntukan untuk merefleksikan pelaksanaan pembelajaran berikutnya. Data kualitatif yang berupa informasi berbentuk kalimat yang memberi gambaran tentang ekspresi peserta didik berkaitan dengan tingkat pemahaman terhadap mata pelajaran geografi (kognitif), serta pandangan peserta didik terhadap metode pelajaran peta pikiran (afektif).

\section{e. Indikator keberhasilan}

Pada penelitian ini indikator keberhasilan yang ditetapkan adalah angka 65. Nilai tersebut didasarkan pada Kriteria Ketuntasan Minimum (KKM) mata pelajaran geografi yang ditetapkan oleh SMAN 1 Rasau Jaya. Maka, seorang peserta didik dinyatakan berhasil atau tuntas apabila telah mampu; (a) membuat peta pikiran dan mengdentifikasi 20 konsep, mengelompokkan 10 konsep serta mengeneralisasi 5 konsep; (b) peserta didik mengumpulkan tugas yang diberikan oleh guru dengan tepat waktu beserta kelengkapan isi dari LKS tersebut; (c) peserta didik mampu mempresentasikan konsep geografi menggunakan peta pikiran; dan (d) memperoleh nilai tes minimum 65. Indikator keberhasilan yang ditetapkan adalah apabila $75 \%$ dari jumlah peserta didik atau sekitar 18 peserta didik mencapai KKM.

\section{Hasil Pembahasan}

Peningkatan pemahaman konsep peserta didik menggunakan teknik peta pikiran dibuktikan dengan adanya peningkatan nilai disetiap tindakan. Pada siklus 1 tindakan pertama peserta didik yang mampu mengidentifikasi, mengelompokkan dan mengeneralisasikan konsep menjadi sebuah peta pikiran sebanyak 13 peserta didik atau $55 \%$ dengan nilai $\mathrm{KKM} \geq 65$ dengan rata-rata nilai peserta didik yaitu sebesar 60.46. Pada siklus 1 tindakan kedua kemampuan peserta didik terdapat peningkatan dilihat dari banyaknya peserta didik yang mendapatakan nilai $\geq 65$, sedangkan yang mendapatkan nilai < 65 hanya 2 peserta didik dikarenakan tidak hadir saat pembelajaran berlangsung dan rata-rata nilai peserta didik yaitu sebesar 69.31.

Pada siklus 2 tindakan pertama, peserta didik sudah dengan mudah mengidentifikasi, mengelompokkan serta mengeneralisasikan konsep yang dijadikan peta pikiran. Hal ini ditujukkan dengan adanya peningkatan nilai peta pikiran disetiap peserta didik dengan nilai rata-rata $>65$, hanya 1 peserta didik yang masih di bawah nilai 65 tetapi dia mengalami peningkatan disetiap tindakannya hanya saja berjalan lamban dan rata-rata nilai peserta didik yaitu sebesar 81.67. Pada siklus 2 tindakan kedua pemahaman konsep peserta didik sudah sangat baik hal ini di tunjukkan dengan nilai pembuatan peta pikiran setiap peserta didik yang sudah di atas 85 dengan rata-rata nilai peserta didik yaitu sebesar 86.04. Nilai peta pikiran didapatkan dari pengabungan nilai setiap peserta didik yang telah mengidentifikasi, mengelompokkan, dan mengeneralisasikan setiap konsep yang ada pada bahan ajar.

Peningkatan pemahaman konsep peserta didik juga diukur melalui presentasi peta pikiran yang dilaksanakan pada setiap tindakan. Di setiap tindakan peserta didik yang tampil mempresentasikan peta pikiran sebanyak 6 peserta didik sehingga pada siklus 2 tindakan kedua seluruh peserta didik dapat tampil mempresentasikan peta pikiran. Dari nilai presentasi diketahui bahwa 3 peserta didik mendapatkan nilai dibawah KKM atau $<65$. Artinya 3 peserta didik tersebut belum paham terhadap materi yang disampikan sehingga ketepatan materi saat presentasi menjadi kurang baik. Hal ini berpengaruh pada kemampuan menyampikan materi ketepatan waktu saat presentasi.

Berdasarkan nilai tugas lembar kerja peserta didik diketahui bahwa pada siklus 1 tindakan pertama 12 peserta didik atau $50 \%$ peserta didik memiliki nilai diatas KKM dan dapat menuntaskan tugas yang diberikan guru dengan nilai rata-rata 61.42. Pada siklus 1 tindakan kedua peningkatan 
jumlah peserta didik yang dapat menuntaskan tugas lembar kerja peserta didik meningkat menjadi 20 peserta didik atau $83.34 \%$ peserta didik memiliki nilai diatas KKM dan dapat menuntaskan tugas yang diberikan guru dengan nilai rata-rata 74.58. Pada siklus 2 tindakan pertama dan siklus 2 tindakan kedua jumlah peserta didik yang dapat menuntaskan tugas lembar kerja peserta didik meningkat menjadi 21 peserta didik atau $87.5 \%$ peserta didik memiliki nilai diatas KKM dan dapat menuntaskan tugas yang diberikan guru, dengan nilai rata-rata peserta didik pada siklus II tindakan pertama yaitu sebesar 79.58 dan pada siklus II tindakan kedua nilai rata-rata yaitu sebesar 82.71.

Dari keseluruhan data yang diperoleh menunjukkan bahwa penelitian tindakan kelas dengan menggunakan teknik peta pikiran (Mind Map) dapat meningkatkan pemahaman konsep geografi peserta didik. Upaya untuk meningkatkan pemahaman konsep geografi peserta didik, termasuk memahami dan mempelajari konsep geografi misalnya dalam pola belajar setiap peserta didik maka prilaku belajar merupakan perwujudan dari perubahan yang terjadi dalam setiap individu perserta didik. Menurut Muhibbinsyah (2013:116) menyatakan bahwa "perwujudan perilaku belajar tersebut antara lain; (1) kebiasaan, (2) keterampilan, (3) pengamatan, (4) berpikir asosiatif dan daya ingat, (5) berpikir rasional dan kritis, (6) sikap, (7) Inhibisi, (8) Apresiasi, dan (9) tingkah laku efektif". Menurut DePotter (2013:146) menyatakan bahwa "peningkatan pemahaman konsep sesuai dengan perwujudan perilaku belajar berpikir asosiatif dan daya ingat". Memahami konsep dapat dipermudah melalui mencatat sebab mencatat dapat meningkatkan daya ingat dan dapat membatu mengingat apa yang tersimpan dalam memori.

Bloom (1978:90) dalam Muhibbinsyah (2013:25) menyatakan bahwa pemahaman mencakup tujuan, tingkah laku, atau tanggapan yang mencerminkan sesuatu pemahaman pesan tertulis yang termuat dalam satu komunikasi”. Sehingga peserta didik dituntut memahami atau mengerti apa yang diajarkan, mengetahui apa yang sedang dikomunikasikan dan dapat memanfaatkan isinya tanpa keharusan menghubungkan dengan hal-hal yang lain. Peserta didik dikatakan paham terhadap sesuatu materi ajar, apabila peserta didik dapat mengerti benar dan mampu menjelaskan kembali materi ajar tersebut. Bloom (1978: 90) menyatakan "Pemahaman konsep yang diukur terdiri dari tiga kategori, yaitu Translasi, Interpretasi, dan ekstrapolasi". Pada tahapan translasi peserta didik diminta untuk mengidentifikasi dan mengelompokkan konsep yang ada pada bahan ajar. Pada tahapan interpretasi peserta didik untuk memahami konsep dengan cara menganalisis dan menafsirkan konsep yanga ada pada bahan ajar. Sedangkan pada tahapan ekstrapolasi peserta didik dituntut untuk mampu mengeneralisasikan dan menyimpulkan konsep yang ada. Konsep yang telah diidentifikasi, dikelompokkan, dan digeneralisasikan akan dibuat menjadi sebuah peta pikiran. Sedangkan pada saat presentasi, peserta didik diminta untuk menjelaskan dan menyimpulkan materi yang sedang diajarkan. Jika tahapan-tahapan tersebut telah dilakukan oleh setiap peserta didik maka peserta didik tersebut telah memiliki pemahaman konsep yang baik.

Berdasarkan hasil observasi yang diamati oleh observer, pada siklus 1 tindakan pertama banyak sekali kekurangan-kekurangan yang berasal dari guru maupun peserta didik itu sendiri. Seperti pada awal kegiatan guru masih kebinggungan dalam memulai pembelajaran menggunakan teknik peta pikiran. Guru juga belum bisa mengatur waktu sehingga berdampak ada beberapa langkah pembelajaran yang tidak dilaksanakan seperti tidak menjelaskan petunjuk belajar dan petunjuk penyelesaian kerja. Hal ini berpengaruh terhadap tingkat pemahaman konsep peserta didik pada siklus 1 tindakan pertama masih belum menunjukkan peningkatan dikarenakan peserta didik masih belum terbiasa dengan pembelajaran yang dilakukan. Dari sisi peserta didik sikap acuh tak acuh pada materi pelajaran, dan banyak peserta didik yang tidak membaca bahan ajar membuat suasana kelas kurang kondusif. Banyak peserta didik yang melakukan aktivitas menyimpang seperti mengobrol dengan teman sebangku, mengerjakan peer di luar mata pelajaran geografi, rebut dan lain sebagainya. Dalam hal ini guru kurang sigap dan kurang tegas dalam mengahadapi sikap peserta didik yang mengganggu aktivitas belajar tersebut. Pelaksanaan siklus 1 tindakan pertama ini dikatakan belum mencapai tujuan pembelajaran. Tujuan pembelajaran merupakan tolak ukur keberhasilan dalam mengajar. Faktor-faktor yang mempengaruhi keberhasilan adalah tujuan. Dimana tujuan itu sendiri adalah pedoman sekaligus sebagai sasaran yang akan dicapai dalam kegiatan mengajar berpangkal 
dari jelas tidaknya perumusan tujuan pengajaran. Tercapainya tujuan sama halnya keberhasilan pengajaran (Bahri dan Zain, 2006, dalam Priatna 2012:114).

Dari keseluruhan data yang diperoleh disetiap tindakan diperoleh kesimpulan bahwa penelitian tindakan kelas dengan menggunakan teknik peta pikiran dapat meningkatkan pemahaman konsep geografi peserta didik di kelas XI IPS 2 SMAN 1 Rasau Jaya. Hal ini dapat dilihat dari tercapainya semua indikator keberhasilan. Dengan demikian, indikator keberhasilan dalam penelitian telah terpenuhi serta menjawab hipotesis atas tindakan yang dilakukan yaitu Penerapan Teknik Peta Pikiran dapat meningkatkan pemahaman konsep geografi pada peserta didik Kelas XI-2 IPS SMAN 1 Rasau Jaya. Penggunaan teknik peta pikiran dalam pembelajaran geografi memiliki banyak keutungan, terutama dalam mengatasi banyaknya materi yang ada pada setiap pokok bahasan. Sehingga materi ajar yang ada dapat tersampaikan dengan tepat waktu tanpa melewatkan setiap bagian dalam pokok bahasan. Peserta didik juga bisa dengan mudah memahami konsep yang ada pada setiap pokok bahasan sehingga dapat meningkatkan pemahaman konsep yang ada pada diri setiap peserta didik.

\section{Penutup}

1) Penerapan teknik peta pikiran dalam mata pelajaran geografi dapat mempermudah guru dalam mengatasi banyaknya materi ajar dalam satu pokok dengan tepat waktu. Penerapan teknik peta pikiran juga dapat meningkatkan kemampuan mengingat dan mengungkapkan kembali konsep, sehingga pemahaman peserta didik dalam memahami materi ajar akan mudah melalui peta pikiran.

2) Keberhasilan penerapan teknik peta pikiran dalam meningkakan pemahaman konsep peserta didik merupakan suatu upaya perbaikan mutu pembelajaran khususnya pembelajaran geografi. Upaya perbaikan tersebut tidak terlepas dari kerjasama antara guru dan peserta didik sebagai pelaksana kegiatan pembelajaran serta kondisi lingkungan dimana peserta didik beraktivitas baik itu lingkungan keluarga, lingkungan sekitar sekolah maupun lingkungan masyarakat.

3) Pelaksanaan pembelajaran dilakukan dalam dua siklus dan berakhir pada siklus 2 tindakan kedua dikarenakan secara keseluruhan nilai disetiap tugas yang diberikan sudah mencukupi nilai KKM yaitu 65. Artinya $75 \%$ dari jumlah peserta didik atau sekitar 18 peserta didik dinyatakan berhasil dalam mencapai nilai KKM dan berhasil dalam belajar menggunakan teknik peta pikiran untuk meningkatkan pemahaman konsep. Dari evaluasi akhir pembelajaran hanya 3 peserta didik yang belum memenuhi nilai KKM yaitu $<65$. Sedangkan 21 peserta didik lainnya berada di atas nilai $\mathrm{KKM}$ atau $\geq 65$, nilai ini dapat dilihat pada lampiran. Adapun nilai rata-rata hasil evaluasi peserta didik yaitu sebesar 74.88.

4) Peningkatan pemahaman konsep geografi juga tidak hanya dialami oleh peserta didik. Dari hasil observasi yang dilakukan oleh peneliti diketahui bahwa guru geografi kelas XI di SMAN 1 Rasau Jaya juga mengalami peningkatan keterampilan dalam menggunakan peta pikiran, menciptakan suasana belajar yang menyenangkan dan memotivasi peserta didik disetiap pertemuannya. Peningkatan oleh guru juga terjadi saat guru merefleksikan dan mempersiapkan rencana pelaksanaan pembelajaran dan bahan ajar, dimana guru merasa antusias mengungkapkan kekurangan yang ada pada pembelajaran yang telah berlangsung dan memberikan masukan pada saat penyusunan kembali rencana pelaksanaan pembelajaran.

5) Hambatan yang dihadapi dalam penggunaan teknik Peta Pikiran selama pelaksanaan penelitian tindakan kelas pada peserta didik kelas XI-2 IPS SMAN 1 Rasau Jaya antara lain; (a) Teknik peta pikiran belum pernah digunakan guru geografi di SMAN 1 Rasau Jaya, sehingga sebelum proses pembelajaran dilaksanakan peneliti harus melatih guru model proses pembelajaran menggunakan teknik peta pikiran; (b) menajemen waktu yang kurang baik dalam proses pembelajaran; (c) peserta didik kurang memiliki ketekunan dan ketelitian saat membaca materi ajar dan menuliskan peta pikiran; dan (d) kemampuan mengingat dan mengungkapkan kembali konsep yang masih lemah sehingga saat presentasi beberapa peserta didik lupa dengan materi yang telah dipelajari. 


\section{Daftar Pustaka}

Buzan, Tony. 2012. Buku Pintar Mind Map. Jakarta: Gramedia

Dahar, Ratna Wilis. 2006. Teori-teori Belajar dan Pembelajaran. Jakarta: Erlangga

DePorter, Bobbi. 2013. Quantum Learning. Bandung: Kaifa

Dimyati. 2013. Belajar dan Pembelajaran. Jakarta: Rineke Cipta

Muhibbinsyah. 2013. Psikologi Pendidikan: Dengan Pendekatan Baru. Bandung: Remaja Rosdakarya.

Ningrum, Epon. 2009. Kompetensi Profesional Guru Dalam Konteks Strategi Pembelajaran. Bandung: Buana Nusantara.

Ningrum, Epon. 2009. Penelitian Tindakan Kelas: Panduan Praktis dan Contoh. Bandung: Buana Nusantara.

Sumarmi. 2012. Model-Model Pembelajaran Geografi. Yogyakarta: Aditya Media. 